\title{
Follow-up of citations of maritime epidemiological injury studies
}

\author{
Olaf Chresten Jensen ${ }^{1,3,4} \oplus$, Agnes Flores ${ }^{2} \oplus$, Fereshteh Baygi ${ }^{1}{ }^{\oplus}$, \\ Despena Andrioti Bygvraa $^{1}\left({ }^{\circledR}\right.$, George Charalambous ${ }^{3}$ \\ ${ }^{1}$ Centre of Maritime Health and Society, Department of Public Health, University of Southern Denmark, Esbjerg, Denmark \\ ${ }^{2}$ Caja Seguro Social, Rep. of Panamá, Vacamonte, Panama \\ ${ }^{3}$ Graduate School, Frederick University, Nicosia, Cyprus \\ ${ }^{4}$ School of Medicine, University of Panama
}

\begin{abstract}
Background: The article is based on a review and follow-up of the citations of 13 epidemiological studies that aimed to improve maritime health and safety. While it's well-recognised that epidemiology is needed in occupational health and safety, the main research question: "How can epidemiology help workers to return healthy from the sea" was unanswered.

Materials and methods: The 13 articles were selected as a representative sample of different epidemiological design studies intended to contribute to improving safety management in fishing, merchant shipping and offshore industry. The PubMed, Research Gate, Cochrane-Library and Google Scholar were searched for authors that had cited our articles by using full bibliographic information and the results analysed.

Results: In all, 213 citation records were identified. After duplicates and records with insufficient information were removed, 123 full-text articles were eligible for evaluation with answers to the research questions: how did other authors use the studies, how has the injury epidemiology been developed, which recommendations are given for new policies and new studies and how can epidemiology help workers return safe and healthy from the sea? Conclusions: The answer to the main research question is yes, epidemiological studies are not only useful but a necessary component by providing the needed evidence for successful prevention programmes.
\end{abstract}

(Int Marit Health 2020; 71, 1: 62-70)

Key words: epidemiology, injury, fishing, seafaring, citations, maritime

\section{INTRODUCTION}

The review is based on 13 published articles that aim to improve the safety in the maritime sector and a follow-up of the citations by other authors in published studies.

While epidemiological studies in the maritime health and safety domains were rare until the 1990s, these studies can be seen as pioneering in the maritime injury epidemiology. The method of follow-up of the citing articles is a new method that is supposed to improve the methods and to find new results.

Each of the selected collection of 13 studies highlights some specific design studies in injury epidemiology (Table 1). The articles represent different types of study-design like register-based cohorts, cross-sectional questionnaire studies, case-referent study based on registers of injuries in seafaring, fishing and offshore workers in the oil and gas industry. The studies are for the main part based on the Danish fishermen and seafarers and some of them are from international collaborations.

Concerning the study populations, there are about 1.6 million merchant seafarers and 35 million fishermen and they together with the offshore workers contribute to a significant part of the European and the global economy [1]. Important common characteristic for merchant seafarers, fishermen and offshore workers is that they are away from home, staying on the ships and oil platforms at sea for weeks, months and even half of years. This poses some specific living and working conditions that is supposed to have some significant health impact in a short- and longer-time perspective.

While epidemiology of diseases has been developed over more than 100 years, the practice of occupational 
Table 1. Summary of the selected studies for review

\begin{tabular}{|c|c|c|c|}
\hline & Materials & Methods & Main results \\
\hline \multicolumn{4}{|l|}{ 1. Mortality and injury } \\
\hline $\begin{array}{l}\text { 1. Jensen (1996) } \\
\text { Mortality in fishing }\end{array}$ & $\begin{array}{l}\text { Danish commercial fishermen } \\
1970-1985 \text { compared to all } \\
\text { economically active men ( } 60974 \\
\text { fisherperson-years ( } 375 \text { deaths) }\end{array}$ & $\begin{array}{l}\text { Cohort study. Standardised mor- } \\
\text { tality ratio was calculated from } \\
\text { the death register and population } \\
\text { housing data }\end{array}$ & $\begin{array}{l}\text { High mortality due to accidents, } \\
\text { and increased risk from cancer, } \\
\text { respiratory and cardiovascular } \\
\text { diseases }\end{array}$ \\
\hline $\begin{array}{l}\text { 2. Jensen et al. (2014) } \\
\text { Fatal accidents in fishing } \\
\text { review study }\end{array}$ & $\begin{array}{l}\text { Scientific articles and reports from } \\
\text { the maritime authorities in } 8 \text { Nor- } \\
\text { thern countries } 1990-2014\end{array}$ & $\begin{array}{l}\text { The original incidence rates were } \\
\text { recalculated as per } 1000 \text { person } \\
\text {-years for international comparison } \\
\text { of the trends }\end{array}$ & $\begin{array}{l}\text { Fatal injury rates decreased by } \\
\text { around } 50 \% \text { due to implemented } \\
\text { safety programmes }\end{array}$ \\
\hline $\begin{array}{l}\text { 3. Jensen et al. (2014) } \\
\text { Fatal and non-fatal injuries } \\
\text { in the offshore oil and gas } \\
\text { production }\end{array}$ & $\begin{array}{l}\text { A literature review was performed } \\
\text { by literature search and by exami- } \\
\text { ning national databases }\end{array}$ & $\begin{array}{l}\text { Search and examining PubMed, } \\
\text { Embase, Google Scholar and } \\
\text { Web of Science }\end{array}$ & $\begin{array}{l}\text { Non-fatal injuries offshore decre- } \\
\text { ased. The few epidemiological } \\
\text { studies does not allow for firm } \\
\text { conclusions }\end{array}$ \\
\hline \multicolumn{4}{|l|}{ 2. Injuries in fishing } \\
\hline $\begin{array}{l}\text { 4. Jensen et al. (2005) } \\
\text { Classification of working } \\
\text { processes }\end{array}$ & $\begin{array}{l}\text { The work processes were described } \\
\text { and classified in } 17 \text { main and up to } \\
13 \text { subsidiary work tasks }(n=550)\end{array}$ & $\begin{array}{l}\text { The injuries were coded according } \\
\text { to the developed classification } \\
\text { system }\end{array}$ & $\begin{array}{l}\text { Preparing, shooting and hauling of } \\
\text { the gear constitute about } 50 \% \text { of } \\
\text { all injuries }\end{array}$ \\
\hline $\begin{array}{l}\text { 5. Jensen et al. (2006) } \\
\text { Injury and time studies }\end{array}$ & $\begin{array}{l}\text { Time measurements for the } \\
17 \text { main and } 13 \text { subsidiary working } \\
\text { processes analysed during fishing } \\
\text { trips in } 4 \text { vessel types }\end{array}$ & $\begin{array}{l}\text { Injury reports in a 5-year period } \\
\text { were allocated to the specific } \\
\text { working processes and risk index } \\
\text { numbers calculated }\end{array}$ & $\begin{array}{l}\text { Especially high risk for embarking } \\
\text { and disembarking but also for } \\
\text { other work processes }\end{array}$ \\
\hline $\begin{array}{l}\text { 6. Jensen (2006) } \\
\text { Injury risk at work processes }\end{array}$ & $\begin{array}{l}\text { The reported injuries }(n=550) \text { to } \\
\text { the National Maritime Authorities } \\
\text { for 5-years defined the cases }\end{array}$ & $\begin{array}{l}\text { A case-referent design with sam- } \\
\text { ples of person-time as denomina- } \\
\text { tor and the reported injuries as the } \\
\text { nominators }\end{array}$ & $\begin{array}{l}\text { The variations in the odds ratios of } \\
\text { the fishermen continuously shift } \\
\text { between low and high-risk work } \\
\text { processes }\end{array}$ \\
\hline \multicolumn{4}{|l|}{ 3. Injuries in seafaring } \\
\hline $\begin{array}{l}\text { 7. Jensen et al. (2004) } \\
\text { Self-reported injuries } \\
\text { - evaluation of data validity }\end{array}$ & $\begin{array}{l}\text { A pilot study was conducted } \\
\text { ( } n=1068 \text { ) in Finland, Denmark, } \\
\text { the Philippines, Croatia and } \\
\text { Spain using self-completed } \\
\text { questionnaires }\end{array}$ & $\begin{array}{l}\text { Self-reporting duty period was } \\
\text { compared with information from } \\
\text { the crew register of the Maritime } \\
\text { Authority }\end{array}$ & $\begin{array}{l}\text { Self-report of the duration of the } \\
\text { latest tour of duty is useful for } \\
\text { seafarers from merchant ships } \\
\text { but not for ferries }\end{array}$ \\
\hline $\begin{array}{l}\text { 8. Jensen et al. (2005) } \\
\text { Subjective assessment } \\
\text { of safety }\end{array}$ & $\begin{array}{l}\text { A questionnaire study was carried } \\
\text { out in } 11 \text { countries }(n=6461) \\
\text { seafarers who attended a regular } \\
\text { health examination }\end{array}$ & $\begin{array}{l}\text { Multivariate analyses were used } \\
\text { to analyse the occupational safety } \\
\text { on board, hazardous exposures } \\
\text { and the use of personal protection } \\
\text { equipment }\end{array}$ & $\begin{array}{l}\text { Occupational safety was the lowest } \\
\text { among ratings, seafarers }<30 \text { years } \\
\text { of age, in the engine rooms } \\
\text { and dry cargo ships }\end{array}$ \\
\hline \multicolumn{4}{|l|}{ 4. Slips, trips and falls (STF) } \\
\hline $\begin{array}{l}\text { 9. Jensen et al. (2000) } \\
\text { Slips, trips and falls } \\
\text { in fishing }\end{array}$ & $\begin{array}{l}\text { Fishing injuries }(n=582) \text { treated } \\
\text { at the emergency ward and registe- } \\
\text { red in the Nordic Medic Statistical } \\
\text { Committee (NOMESCO) system }\end{array}$ & $\begin{array}{l}\text { The proportion of fall injuries in } \\
\text { different age groups, injury types } \\
\text { (body lesions) and the injury me- } \\
\text { chanisms were analysed }\end{array}$ & $\begin{array}{l}\text { The proportion of fall injuries in } \\
\text { different age groups was U-shaped. } \\
\text { STF injuries was } 25 \% \text { of all }\end{array}$ \\
\hline $\begin{array}{l}\text { 10. Jensen et al. (2000) } \\
\text { Slips, trips and falls } \\
\text { in seafaring }\end{array}$ & $\begin{array}{l}\text { A questionnaire study was carried } \\
\text { out in } 11 \text { countries }(n=6461)\end{array}$ & $\begin{array}{l}\text { The seafarers gave information } \\
\text { on whether they were injured } \\
\text { during their latest tour of duty, and } \\
\text { whether STF preceded the injury }\end{array}$ & $\begin{array}{l}43 \% \text { were STF related. The high } \\
\text { proportion of STF injuries came by } \\
\text { use of a specific question, was it } \\
\text { a STF? }\end{array}$ \\
\hline $\begin{array}{l}\text { 11. Jensen et al. (2010) } \\
\text { Reduction of slips trips } \\
\text { in fishing by intervention }\end{array}$ & $\begin{array}{l}\text { Fishermen tested new boots with } \\
\text { anti-sleeping soles and tried them } \\
\text { out under active fishing for half } \\
\text { a year }(n=161)\end{array}$ & $\begin{array}{l}\text { Questionnaires at baseline and } \\
\text { after half a year to determine the } \\
\text { comfort and possible reduction } \\
\text { of STF }\end{array}$ & $\begin{array}{l}\text { The new boot had significant better } \\
\text { comfort and feeling of firm grip } \\
\text { when standing and walking }\end{array}$ \\
\hline \multicolumn{4}{|l|}{ 5. Working conditions at sea } \\
\hline $\begin{array}{l}\text { 12. Jensen et al. (2006) } \\
\text { Working conditions } \\
\text { in seafaring }\end{array}$ & $\begin{array}{l}\text { Seafarers in } 11 \text { countries ( } n=6461) \\
\text { responded a questionnaire at the } \\
\text { health examinations in the seafa- } \\
\text { rers' clinics }\end{array}$ & $\begin{array}{l}\text { The questions concerning the most } \\
\text { recent tour of duty self-rated health } \\
\text { status and the main characteristics } \\
\text { of working conditions }\end{array}$ & $\begin{array}{l}\text { Most seafarers worked every day } \\
\text { of the week, and on average for } \\
67-70 \text { hours a week during pe- } \\
\text { riods of } 2.5-8.5 \text { months }\end{array}$ \\
\hline $\begin{array}{l}\text { 13. Jensen et al. (2014) } \\
\text { Social security for } \\
\text { seafarers }\end{array}$ & $\begin{array}{l}\text { Seafarers from } 5 \text { countries }(n=127) \\
\text { completed a questionnaire at the } \\
\text { health examinations in the seafa- } \\
\text { rers clinics }\end{array}$ & $\begin{array}{l}\text { The questions concerning their } \\
\text { knowledge about their social } \\
\text { security status on coverage } \\
\text { for disease and retirement }\end{array}$ & $\begin{array}{l}\text { A significant part of the seafarers } \\
\text { comes from the poorer countries } \\
\text { without good social security } \\
\text { systems }\end{array}$ \\
\hline
\end{tabular}


epidemiology was nearly non-existent until 1990 and the development of injury epidemiology and especially in the maritime setting has been a challenge. One of the main challenges is how to get valid nominator and denominator data to yield unbiased epidemiological rates-ratios. Over the latest decennia we have introduced the term "injury" for the body damage and "accident" for the preceding incident [2]. An injury can be defined as a sudden event (caused by an accident) in which an external noxious agent hurts or injures a person. The epidemiological studies of occupational injuries were sparse until the nineteen eighties and injury studies had low interest among the epidemiologists.

\section{THE RESEARCH QUESTIONS}

How did other researchers use the studies?

Which recommendations for preventive policy and prevention are there?

Which recommendations are given for new studies?

How was the maritime occupational injury epidemiology further developed?

How can epidemiology help workers to return healthy from the sea?

\section{MATERIALS AND METHODS}

The methods used in the 13 articles involved a transition from epidemiological descriptive design to more advanced statistical methods in the studies. The studies are divided in five sections: 1 . Mortality and fatal injuries; 2. Injuries in fishing; 3. Injuries in seafaring; 4. Slips, trips and falls; 5. Working conditions at sea.

The 13 articles were selected as a good representative sample of studies contributing to an epidemiological analysis of the occupational risks to improve the safety management in fishing, merchant shipping and offshore industry. Since the aim of this study was to analyse descriptive studies in health and safety in fishing, the criteria were set to achieve this aim. The whole process of search and selection of the citing articles is shown in Table 2.

\section{SEARCH FOR THE CITING ARTICLES}

One by one, the 13 articles in the collection were searched in PubMed Google Scholar by using the full bibliographic information e.g. "Jensen OC. Injury risk at the work processes in fishing: a case-referent study. European Journal of Epidemiology. 2006; 21(7): 521. The searches were repeated in PubMed, Cochrane and Research Gate to see if more citing articles come up. The citing articles were searched from $1^{\text {st }}$ October 2017 to $31^{\text {th }}$ October 2018. The follow-up time for the sample of the citations varies from the first publication in 1996 to the latest included in 2014.

\section{INCLUSION CRITERIA OF THE CITING ARTICLES}

The first step was to systematise and analyse the citing articles and to define the eligibility criteria for the citation articles to be included. All types of epidemiological design, in English or Spanish were included: literature reviews, cross-sectional, cohort and case-control studies. Only peer reviewed scientific articles were included.

\section{EXCLUSION CRITERIA OF THE CITING ARTICLES}

Articles or thesis in languages not understood by the author, like Indonesian, Chinese, Finnish or other languages are excluded. Administrative reports are excluded.

\section{ETHICAL ISSUES}

The review work does not involve any personal participant and company information, and so the study does not involve ethical problems. All data is processed according to the medical duties act, as well as the guidelines for good epidemiological practice is followed.

\section{RESULTS}

In all 213 citation records were identified through database searching and additional free records were identified through other articles. After removal of 17 duplicates and 22 records with insufficient information, a total of 199 records remained for screening. Of those 76 were excluded due to either lack of full text or other problems. The final 123 full-text articles were eligible for evaluation (Fig. 1). Twenty-five were included in the quantitative synthesis and 90 studies in the qualitative synthesis the articles are distributed in the five main sections: mortality and fatal accidents, injuries in fishing, injuries in seafaring, slips, trips and falls and working conditions in seafaring. The citing articles that used this study as background with no further comments are kept out of this review.

Study 1: Mortality in Danish Fishermen [3]. The study aimed to investigate the mortality patterns in Danish commercial fishermen (1970-1985), compared to all economically active men by the use of standardised mortality ratio with $95 \%$ confidence intervals for all causes among crewmembers was increased for accidents, ischaemic heart diseases, bronchitis and emphysema compared to all economic active men. Of the 13 citations, 3 studies for comparison: $[4,5]$.

Study 2: A review of fatal accident incidence rate trends in fishing international [6]. The review is based on scientific journal articles and some few technical reports from the maritime authorities in Poland, United Kingdom, Norway, Iceland, Denmark, United States and Alaska and Canada. The risk of fatal injuries was reduced by around $50 \%$ to an average of about 1 per 1000 person-years. The safety programmes seem to have good effects, still the risk is 
Table 2. Search and selection procedure of the citing articles

1. Search each of the 13 articles in the databases mentioned by using the full bibliographic information in Vancouver style to identify articles that have cited one or more of the 13 articles

2. Search each of the citing articles one by one in PubMed and/or Google Scholar, and to be registered in 13 separate Zotero bibliographic databases

3. The full-text of citing each article are then searched in PubMed and/or Google Scholar or Research Gate and included in the Zotero database

4. Revise the citing articles one by one, delete duplicates and mark those with and without full-text

5. Exclude citations of no relevance (based on abstract or full-text) foreign languages and not maritime health

6. Evaluate one by one the full text of the citation articles, search for "Jensen" and copy the cited texts articles

7. Copy the citations with "snapshot" and paste them in the "Citation Archives" for evaluation

8. Classify the copied information according to the 5 classification points in PRISMA: doublet, exclusion of other reason, quantitative/ /qualitative useful, full-text/non-full text in (Liberati et al. 2009)

9. Construct a "selection tree" scheme for each of the 13 articles

10. Transfer the results to a sum scheme for all the 13 articles (Fig. 1)

11. Analysis, systematise and sum up the relevance of the citations in the Results section

12. Answers the research questions based on the 13 selected articles and the citing articles

13. Sum up in the conclusions on the gained new knowledge on methods and evidence for new prevention policies

14. Sum up the recommendations from the 13 articles and the citing articles about the needed prevention, policies for prevention and for new research

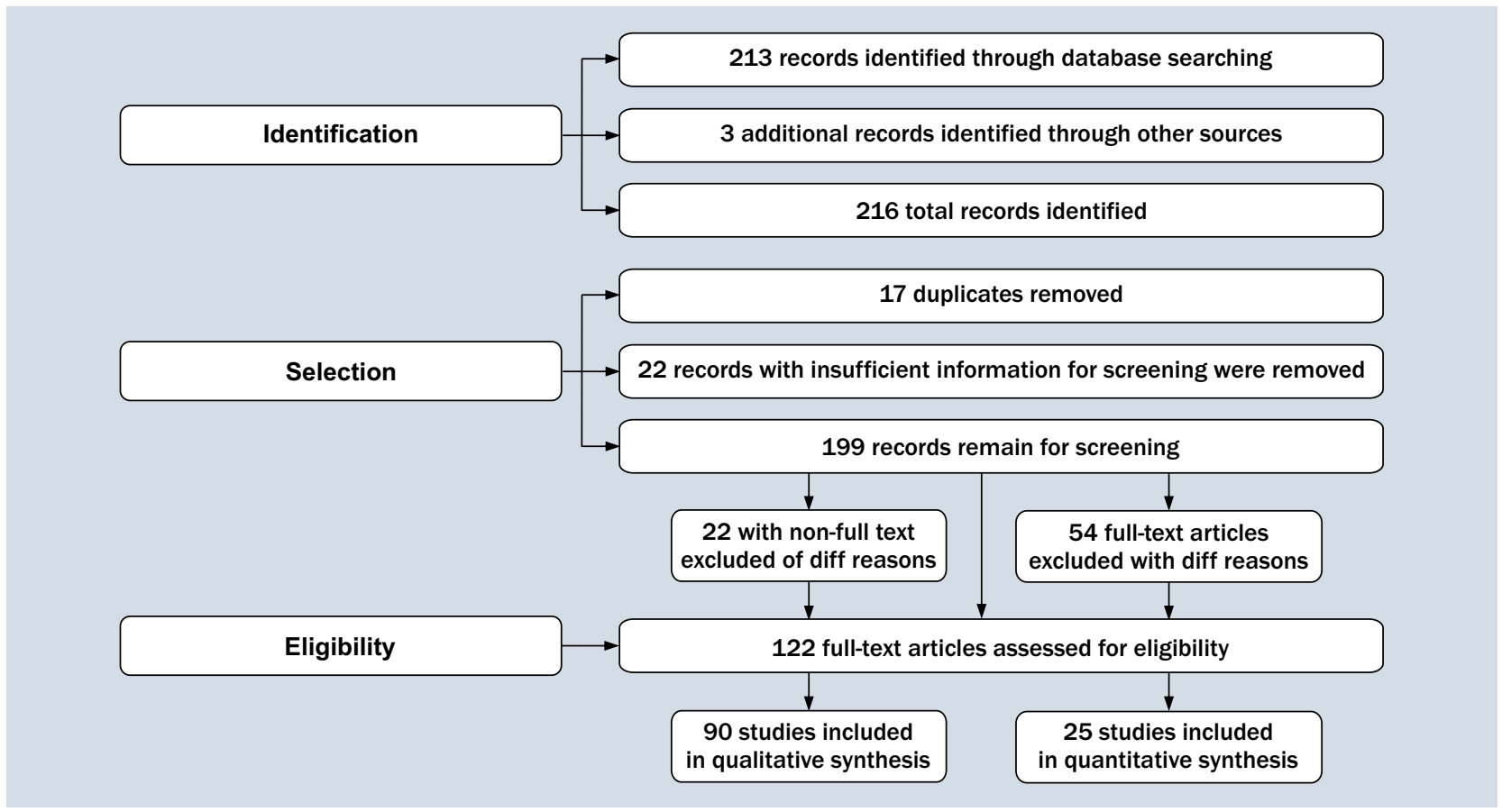

Figure 1. Selection tree of the "citing articles" included in the review

about 25 to 50 times higher than for onshore workers. Of the 13 citations, 5 were excluded, 2 doublets, 2 were used as background references and 3 for comparison of the quantitative results.

Study 3: A review of epidemiological injury studies in the oil and gas offshore industry with the objectives to evaluate the preventive programmes effect [7]. The fatal injuries in the oil and gas production in the US are seven times higher than for other workers in the US and the rate increased.

Study 4: Classification and coding of commercial fishing injuries by work processes: an experience in the Danish fresh market fishing industry [8]. This study was an answer 
to the lack of a detailed classification system for fishing accidents and relates closely to Study 3 . The objective was to describe all main work processes to create a new classification system to be used for injury prevention. The working processes were described and a classification catalogue with 17 main categories and up to 13 associated subsidiary categories for each of the fishing methods were prepared. All fishing injury reports to the Danish Maritime authorities for 5 years were coded according to the specific type of vessel and the specific working process where the injuries happened. The study was cited by 15 authors in the introduction of their studies and discussed in other studies.

Study 5: Injury and time studies of the working processes in fishing. The objective was to solve the methodical problem that the use of a common overall denominator, e.g. days at sea related to different working processes on board is not useful to estimate the incidence rates for the specific working processes. To solve the problem there was a need to estimate the more precise use of working time for specific working processes in typical types of professional fishing. The working time for the specific working processes in fishing was related to the number of injuries related to the same working processes [9]. The study was cited by 15 authors in the introduction of their studies but also in the discussion of some of the studies.

Study 6: Injury risk at the work processes in fishing: a case-referent study [10]. The aim of the study was to estimate the injury rate-ratios for the main work processes in commercial fishing. The problem is that epidemiological studies describe the incidence ratios only related to the main strata in the industries, while the injury incidence ratios for the specific work processes within the workplaces have not yet been studied. The study was cited by 12 authors in the introduction of their studies but also in the discussion of some of the studies.

Study 7: Self-reported injuries among seafarers. Questionnaire validity and results from an international study [11]. The aim was to test the method of self-report of injuries and length of time at risk during the latest duty period and second to study the injury incidence rate among seafarers by use of the method. 32 authors cited the study.

Study 8: Subjective assessments of safety, exposure to chemicals and use of personal protection equipment in seafaring. The objective was to describe the seafarers' assessments of the occupational safety on board, their exposure to chemicals and the use of personal protection equipment and to identify the areas for further risk assessment and preventive measures [12]. A questionnaire study was carried out in 11 countries among seafarers who attended a regular health examination. The study was cited by 11 authors, some in the introduction and others in the discussion of their studies as commented in the discussion.
Study 9: Non-fatal occupational fall and slip injuries among commercial fishermen analysed by use of the Nordic Medic Statistical Committee (NOMESCO) injury registration system [13] in order to add more detailed information about slips, trips, and falls on board fishing vessels. Data on fishing injuries treated at the emergency ward at Esbjerg Central Hospital was registered in the NOMESCO injury registration system [14] and 38 authors cited the study.

Study 10: Non-fatal occupational injuries related to slips, trips and falls in seafaring [15]. Merchant seafaring often involves hazardous occupational operations and several studies have shown increased fatal injury incidence often related to slips, trips and falls on board and falls overboard $[16,17]$. In all 27 authors cited the study.

Study 11: Reduction of slips, trips and falls and better comfort using new anti-slipping boots in fishing [18]. One hundred and fifty fishermen participated in the study with a baseline questionnaire and repeated the questionnaire after they had used the new boots for half a year. The result was that the new boots were considered as much better or somewhat better by $90 \%$ of the fishermen reporting they had a good grip on the deck and a feeling of standing firmly. In all 6 authors cited the study

Study 12: Working conditions in international seafaring [19]. The objective was to describe the self-rated health and the main characteristics of the seafarers working conditions. A total of 6461 seafarers in 11 countries responded to a questionnaire concerning the most recent tour of duty. In general, the seafarers' self-rated health was good, but it declined significantly with age. 20 authors cited the study,

Study 13: Social security for seafarers globally [20]. The seafarers completed a short questionnaire concerning their knowledge about their social security status. The significant disparities in the social security coverage were pointed out among the nationalities. The solutions suggested are to implement the minimum requirements as recommended by the International Labour Organisation 2006 Convention, to survey the implementation and in the long term to struggle for a global social equality. The only one citation was from one of the co-authors.

\section{DISCUSSION}

This is to our knowledge the first study to follow-up on how other authors have cited and used a sample of studies. Contributions from the citing articles to the main research questions are identified and discussed.

\section{HOW DID OTHER RESEARCHERS USE THE STUDIES FOR COMPARISONS?}

In contrast to our Danish Study 1, the Swedish fishermen had lower mortality rates from: all causes, malignancies, respiratory and cardiovascular diseases compared to 
other men [4]. The similar pattern was found for Finnish fishermen with lower mortality from: all causes, ischemic heart diseases, cerebrovascular diseases and malignant neoplasms than the general population [5]. Study 4 and 6 on classification and coding of injuries by the work processes was followed by several other authors: Syron et al. [21] utilised our system to code non-fatal injury cases to point out the most frequent work processes associated with non-fatal injuries. Krenz et al. [22] also found the "Jensen" System useful for activity classification for claims. Lucas et al. [23] applied a framework based on our system to code processes specifically related to long-liners and trawlers. McGuiness and Piniella et al. [24] points out the need for specific classification of the working processes for more effective prevention [25].

Study 7 on self-reported injuries among seafarers was used by among others Shan [26]. Study 9, on the occupational fall and slip injuries in fishermen coded according to the Nordic Medico Statistical Injury Registration System was used by Bull et al. [27] who found similar high percentages of slips, trips and falls in fishing. Study 10 on slips, trips and falls (STF) in merchant seafaring was followed by several authors confirming that STF related injuries especially in the engine rooms need to be taken in attention for better prevention $[28,29]$. Study 11 on the fishermen's test of new boots with anti-slipping soles was commented by Lucas et al. [30] who mention the resistance to introduce new type of footwear and that good footwear can hinder falls overboard and save life's [30-32].

\section{HOW WAS THE MARITIME OCCUPATIONAL INJURY EPIDEMIOLOGY FURTHER DEVELOPED?}

Study 1: The methods used in epidemiology have changed radically from using paper forms to pure digitalised data over the latest half century. This great development in the epidemiology permits to handle big amount of data with advanced statistical methods, especially the multiple regression analysis [33]. Study 2: The review of fatal injuries in fishing [6], shows an overall decrease of the fatal incidence rates over the last decades. The study showed that trends can be compared for the first time with meaning for the planning of the prevention activities. In Study 5 and 6, the injury and time studies of the working processes in fishing was new and opens up for a more specific and effective prevention of the injuries in fishing. The aim was to estimate the relative risks for specific working processes in order to focus the prevention on the specific work processes. The use of the case-control study design in occupational injury studies is rare and the new method by using the samples of time for the work processes as the denominators is new. The injury epidemiology in merchant seafaring was further developed in Study 7 by asking for the precise number of days at sea in order to obtain precise denominator data for calculation of the Incidence risks and relative risks the first time. The subjective assessment of safety, exposure to chemicals and use of personal protection equipment in seafaring in an international setting was documented for the first time in Study 8. A solution to the methodological problems by using proportionate risk estimates in Study 9 was proposed by multiplication the proportions with the estimates of the incidence rates of all injuries [34]. Based on the learning from the NOMESCO Study 9 , the seafarers were asked specifically whether slips trips and falls preceded the occurrence of the injury in Study 10. The method was new and not surprising that injuries related to STF on merchant ships were more frequent than the previous estimates. The experiment of the use of good footwear for fishermen in Study 11 was new and commented by various authors. In the development of epidemiology, we have moved from Haddon's Matrix to the modern epidemiological sociological model of the ethology to be used for prevention. We have also moved excellently forward since the era where "accident" epidemiology was not recognised as scientific discipline e.g. that injury epidemiology is nearly absent [35].

\section{WHICH RECOMMENDATIONS FOR PREVENTIVE POLICY AND PREVENTION ARE THERE?}

Based on the trend's analyses of fatalities in fishing in Study 2, the preventive programs seem to have good effects. Still, the authors call for continued effort to improve safety in fishing in all the studies $[23,30,36]$.

According to the authors comments on Study 4, 5 and 6 the analysis of the specific risk at the different work processes is recommended to identify hazardous tasks [21]. Future prevention efforts should target work processes associated with the most frequent and most severe injuries by using time estimates for work processes in order to determine risk estimates.

Our proposal of the need for better trauma prevention on board in Study 7 was supported by several authors [37-39]. The main recommendation from Study 11 is to encourage fishermen to replace their boots as soon as they are worn out and that risk assessments of fishing vessels should include assessment of footwear. The recommendations in study 12 include that further studies are necessary to describe more closely the influence of work schedules on the health and social life of seafarers. Patella et al. [40] cite us because we supply the documentation that the engine crew suffer the highest overall levels of stress followed by the deck and engine officers. Österman and Hult [41] cite us because we say that the seafarers work and live between 2 to 8 months on board continuously exposed small possibilities for recreation together with people of various backgrounds and nationalities. 
Oldenburg et al. [42] again refer to our study to find out the very long stay on board after 10 months on the conditions with permanent physical factors noise and vibration post on the working and leisure time has a physical and mental effect on the quality of life. Rydstedt et al. [43] again refer to our study concerning the engine room personnel with the highest mental health problems. Oldenburg and Jensen [44] 2012 support and cite our study about the extreme work press also mention that we found nearly 70 work all hours per week for both officers and none officers per week. In Study 8, the use of personal protective equipment was assessed to be too low among some parts of the crew and in some working areas and types and sizes of ships. Several authors cited our article and agreed there is a need to improve the safety and the prevention of the risks on board [45-47].

\section{WHICH RECOMMENDATIONS ARE GIVEN FOR NEW STUDIES?}

Several studies underscore the lack of international requirements to harmonise the registration of injuries in fishing for prevention $[24,48]$. In Study 7 it was concluded that subjective data about the length of the tour for calculating the incidence rates is useful for merchant ships but not for ferries and other type or permanent employment. When the seafarers have permanent contracts specifying the number of hours or days per year, this can be used for denominator data for calculation of the injury incidence rates. Study 9: By using the NOMESCO system for occupational injuries from falls and slips (STF) some important new issues in the injury epidemiology was realised. The estimated proportion of STF-injuries was more precise and higher than seen before. An analysis based on the free text in the NOMESCO register files, revealed that one fourth of the injuries are related to falls/and slips and thus preventable and constituted $60 \%$ of all injuries to the chest. And then it was realised that giving specific attention to STF-related injuries will give the most precise estimate of STF-injuries for the prevention. To avoid a possible misclassification and underestimation of STF-injuries it was recommended to include an extra specific variable: whether falling or slipping preceded the crash phase of the injury or not. This was utilised later in the international questionnaire study among seafarers [15]. Based on the Danish and the Norwegian studies, the NOMESCO system was found useful for analysis of fishing injuries by data from the emergency rooms. Still, there is no information recorded about the working process, which hinders for effective use in the practical prevention, and this was the subject for the other studies. Study 12 on the social security for seafarers was not followed by other studies.
The gap of knowledge remains and calls for more studies. It is also worth mentioning that qualitative studies should be used for further investigation in this area.

\section{HOW CAN EPIDEMIOLOGY HELP WORKERS TO RETURN HEALTHY FROM THE SEA?}

The study examples illustrate how the evidence from epidemiology contributes to identify the relative risk of fatal and non-fatal injuries and diseases.

In this way the studies are necessary as contributing components to successful prevention.

This is consistent with the definition of epidemiology as being "the study of the distribution and determinants of health-related states or events (including disease), and the application of this study to the control of diseases and other health problems" $[48,49]$. The five steps to risk assessment are carried out by using knowledge from research about the risk in general and knowledge about what is the best prevention. The risk assessment comes from observations and from epidemiological knowledge about the risk in number and severity. Proposals for effective prevention measures also come from epidemiological research.

If the evaluations show there is no or too little effect of the prevention measure we need to amend the prevention type and repeat the evaluation process once more. Seen from a global perspective there is an urgent need to help with epidemiology for fishing and aquaculture in the developing countries, e.g. Latin American and African countries [50].

\section{CONCLUSIONS}

The studies have been useful and contributed to obtain better safety in fishing and seafaring and contributed with new methods in injury epidemiology. The main research question whether epidemiology can help the workers to get home safely from work is answered with a "yes". The studies are needed to establish an optimal prevention planning like architectural plans are needed for successful building construction. To avoid biased results the epidemiological studies, need to be conducted under the highest scientific standards.

The developing countries pose a specific challenge for the epidemiology in fishing and aquaculture with millions of workers in the poorest countries. A supposed high incidence on fatal and non-fatal injuries needs urgently to be documented for political attention and effective prevention.

In a global perspective new emerging risks continue to occur, and surveillance programmes of health and safety are needed and should be developed based on the documented risks from the studies. 


\section{REFERENCES}

1. Petursdottir G. Safety at sea as an integral part of fisheries management. FAO Fisheries Circular No. 966 FIIT/C966 ISSN 04299329. ftp://ftp.fao.org/docrep/fao/003/x9656e/x9656e00.pdf (Accessed March 17, 2014).

2. Langley JD. The need to discontinue the use of the term „accident” when referring to unintentional injury events. Accid Anal Prev. 1988; 20(1): 1-8, doi: 10.1016/0001-4575(88)90009-7, indexed in Pubmed: 3337763.

3. Jensen OC. Mortality in Danish fishermen. Bull Inst Marit Trop Med Gdynia. 1996; 47(1-4): 5-10, indexed in Pubmed: 9101046.

4. Mikoczy Z, Rylander L. Mortality and cancer incidence in cohorts of Swedish fishermen and fishermen's wives: updated findings. Chemosphere. 2009; 74(7): 938-943, doi: 10.1016/j.chemosphere.2008.10.006, indexed in Pubmed: 19041115.

5. Turunen AW, Verkasalo PK, Kiviranta $\mathrm{H}$, et al. Mortality in a cohort with high fish consumption. Int J Epidemiol. 2008; 37(5): 1008-1017, doi: 10.1093/ije/dyn117, indexed in Pubmed: 18579573.

6. Jensen OCC, Petursdottir G, Holmen IM, et al. A review of fatal accident incidence rate trends in fishing. Int Marit Health. 2014; 65(2): 47-52, doi: 10.5603/IMH.2014.0011, indexed in Pubmed: 25231324

7. Jensen 0 , Laursen LHA. review of epidemiological injury studies in the oil-and gas offshore industry. Ann Public Health Res. 2014; 1(1): 1-4.

8. Jensen OC, Stage S, Noer P. Classification and coding of commercial fishing injuries by work processes: an experience in the Danish fresh market fishing industry. Am J Ind Med. 2005; 47(6): 528-537, doi: 10.1002/ajim.20163, indexed in Pubmed: 15898090.

9. Jensen OC, Stage S, Noer P. Injury and time studies of working processes in fishing. Safety Science. 2006; 44(4): 349-358, doi: 10.1016/j.ssci.2005.11.001.

10. Jensen OC. Injury risk at the work processes in fishing: a case-referent study. Eur J Epidemiol. 2006; 21(7): 521-527, doi: 10.1007/ s10654-006-9026-9, indexed in Pubmed: 16850176.

11. Jensen OC, Sørensen JFL, Kaerlev L, et al. Self-reported injuries among seafarers. Questionnaire validity and results from an international study. Accid Anal Prev. 2004; 36(3): 405-413, doi: 10.1016/ S0001-4575(03)00034-4, indexed in Pubmed: 15003586.

12. Jensen OC, Sørensen JFL, Canals ML, et al. Subjective assessments of safety, exposure to chemicals and use of personal protection equipment in seafaring. Occup Med (Lond). 2005; 55(6): 454-458, doi: 10.1093/occmed/kqi056, indexed in Pubmed: 15851410.

13. Jensen OC. Non-fatal occupational fall and slip injuries among commercial fishermen analyzed by use of the NOMESCO injury registration system. Am J Ind Med. 2000; 37(6): 637-644, doi: 10.1002/ (sici)1097-0274(200006)37:6<637::aid-ajim8>3.0.co;2-3, indexed in Pubmed: 10797507.

14. Committee NMS. NOMESCO Classification of External Causes of Injuries. Nordic Medico Statistical Committee, Copenhagen 1997.

15. Jensen OC, Sørensen JFL, Canals ML, et al. Non-fatal occupational injuries related to slips, trips and falls in seafaring. Am J Ind Med. 2005; 47(2): 161-171, doi: 10.1002/ajim.20119, indexed in Pubmed: 15662643.

16. Dahl E. Passenger accidents and injuries reported during 3 years on a cruise ship. Int Marit Health. 2010; 61(1): 1-8, indexed in Pubmed: 20496320.

17. Roberts SE, Hansen HL. An analysis of the causes of mortality among seafarers in the British merchant fleet (1986-1995) and recommendations for their reduction. Occup Med (Lond). 2002; 52(4): 195-202, doi: 10.1093/occmed/52.4.195, indexed in Pubmed: 12091585.

18. Jensen OC, Laursen LH. Reduction of slips, trips and falls and better comfort by using new anti-slipping boots in fishing. Int J Inj Contr Saf Promot. 2011; 18(1): 85-87, doi: 10.1080/17457300.2010.487156, indexed in Pubmed: 20552477.

19. Jensen OC, Sørensen JFL, Thomas M, et al. Working conditions in international seafaring. Occup Med (Lond). 2006; 56(6): 393-397, doi: 10.1093/occmed/kql038, indexed in Pubmed: 16804089.

20. Jensen OC, Lucero-Prisno DE, Haarløv E, et al. Social security for seafarers globally. Int Marit Health. 2013; 64(1): 30-35, indexed in Pubmed: 23788163.

21. Syron LN, Lucas DL, Bovbjerg VE, et al. Utility of a Work Process Classification System for characterizing non-fatal injuries in the Alaskan commercial fishing industry. Int J Circumpolar Health. 2016; 75: 30070, doi: 10.3402/ijch.v75.30070, indexed in Pubmed: 26782030.

22. Krenz J, Spector MJ, Frenkel H. Development of a Surveillance Strategy to Guide Injury Prevention Efforts in the North Pacific Commercial Fishing Industry. 2014. http://deohs.washington. edu/pnash/sites/deohs.washington.edu.pnash/files/documents/ Nonfatal_injury_fishing_final_15Jan2014.pdf (Accessed August 25, 2017).

23. Lucas DL, Case SL. Work-related mortality in the US fishing industry during 2000-2014: New findings based on improved workforce exposure estimates. Am J Ind Med. 2018; 61(1): 21-31, doi: 10.1002/ ajim.22761, indexed in Pubmed: 28833290.

24. McGuinness E, Aasjord $\mathrm{H}$, Utne I, et al. Injuries in the commercial fishing fleet of Norway 2000-2011. Safety Science. 2013; 57: 82-99, doi: 10.1016/j.ssci.2013.01.008.

25. Piniella F, Novalbos JP, Nogueroles PJ. Artisanal fishing in Andalusia (II): Safety and working conditions policy. Marine Policy. 2008; 32(4): 551-558, doi: 10.1016/j.marpol.2007.10.005.

26. Shan D. Seafarers' claims for compensation following workplace injuries and death in China. 2017. http://orca.cf.ac.uk/id/ eprint/97925 (Accessed August 25, 2017).

27. Bull N, Riise T, Moen BE. Mechanisms of occupational injuries reported to insurance companies in Norway from 1991 to 1996. Am J Ind Med. 2001; 39(3): 312-319, doi: 10.1002/1097-0274(200103)39:3<312::aid -ajim1019>3.0.co;2-e, indexed in Pubmed: 11241564.

28. Österman C. Ergonomics: An Uncharted Route to Improved Overall Systems Performance in Shipping. Department of Shipping and Marine Technology, Chalmers University of Technology; 2010. http:// www.san-nytt.se/wp/wp-content/uploads/2010/08/asterman_ergonomics-an_uncharted_route_to_improved_overall_systems_performance_in_shipping-1.pdf (Accessed August 25, 2017).

29. Mallam S, Lundh M. Ship Engine Control Room Design. Proceedings of the Human Factors and Ergonomics Society Annual Meeting. 2013; 57(1): 521-525, doi: 10.1177/1541931213571112.

30. Lucas D, Lincoln J, Carozza S, et al. Predictors of personal flotation device (PFD) use among workers in the Alaska commercial fishing industry. Safety Science. 2013; 53: 177-185, doi: 10.1016/j. ssci.2012.10.002.

31. Lucas DL, Kincl LD, Bovbjerg VE, et al. Work-related traumatic injuries onboard freezer-trawlers and freezer-longliners operating in Alaskan waters during 2001-2012. Am J Ind Med. 2014; 57(7): 826-836, doi: 10.1002/ajim.22310, indexed in Pubmed: 24585666. 
32. Chander H, Garner J, Wade C. Heel contact dynamics in alternative footwear during slip events. Int J Ind Ergon. 2015; 48: 158-166, doi: 10.1016/j.ergon.2015.05.009.

33. Ehrenstein V, Nielsen H, Pedersen AB, et al. Clinical epidemiology in the era of big data: new opportunities, familiar challenges. Clin Epidemiol. 2017; 9: 245-250, doi: 10.2147/CLEP.S129779, indexed in Pubmed: 28490904.

34. Jensen OC, Flores A, Bygvraa DA, et al. How to calculate incidence rates from proportionate data. Int Marit Health. 2019; 70(3): 187-192, doi: 10.5603/IMH.2019.0029, indexed in Pubmed: 31617934.

35. Holland WW, Olsen J, Florey C du V. The Development of Modern Epidemiology: Personal Reports from Those Who Were There. Oxford University Press; 2007. https://www.google.com/books?hl=da\& $|r=\& i d=| f J \times o g L 8|| A C \& o i=$ fnd\&pg $=P R 7 \& d q=$ the + deve lopment+of+modern+epidemiology:+personal+reports+from+those + who + were+there\&ots=vUSEwleoyn\&sig $=S 2 \times G$ GOebSd $1 \times 3 \mathrm{db}$ -WrHxJRa8IFU (Accessed October 3, 2017).

36. Kaustell KO, Mattila TEA, Hurme T, et al. Occupational injuries and diseases among commercial fishers in Finland 1996-2015. Int Marit Health. 2016; 67(3): 163-170, doi: 10.5603/IMH.2016.0031, indexed in Pubmed: 27681217.

37. Kaerlev L, Jensen A, Hannerz H. Surveillance of hospital contacts among Danish seafarers and fishermen with focus on skin and infectious diseases-a population-based cohort study. Int J Environ Res Public Health. 2014; 11(11): 11931-11949, doi: 10.3390/ ijerph111111931, indexed in Pubmed: 25411726.

38. Carter T. Mapping the knowledge base for maritime health: 3 illness and injury in seafarers. Int Marit Health. 2011; 62(4): 224-240, indexed in Pubmed: 22544497.

39. Abaya AR, Roldan S, Ongchangco JC, et al. Repatriation rates in Filipino seafarers: a five-year study of 6,759 cases. Int Marit Health. 2015; 66(4): 189-195, doi: 10.5603/IMH.2015.0038, indexed in Pubmed: 26726888.
40. Palella B, Quaranta F, Riccio G. On the management and prevention of heat stress for crews onboard ships. Ocean Engineering. 2016; 112: 277-286, doi: 10.1016/j.oceaneng.2015.12.030.

41. Österman C, Hult C. Administrative burdens and over-exertion in Swedish short sea shipping. Marit Policy Manag. 2016; 43(5): 569-579, doi: 10.1080/03088839.2016.1154994.

42. Oldenburg M, Jensen $\mathrm{HJ}$, Wegner R. Burnout syndrome in seafarers in the merchant marine service. Int Arch Occup Environ Health. 2013; 86(4): 407-416, doi: 10.1007/s00420-012-0771-7, indexed in Pubmed: 22526089.

43. Rydstedt LW, Lundh M. Work demands are related to mental health problems for older engine room officers. Int Marit Health. 2012; 63(4): 176-180, indexed in Pubmed: 24595972.

44. Oldenburg $\mathrm{M}$, Jensen $\mathrm{HJ}$. Merchant seafaring: a changing and hazardous occupation. Occup Environ Med. 2012; 69(9): 685-688, doi: 10.1136/oemed-2011-100619, indexed in Pubmed: 22718706.

45. Brattberg J, Hulthén H. TV\a akomponentsfärg till sjöss. http:// publications.lib.chalmers.se/records/fulltext/212719/212719. pdf (Accessed August 25, 2017).

46. Andruškienè J, Barsevičienè Š, Varoneckas G. Poor sleep, anxiety, depression and other occupational health risks in seafaring population. Trans Nav Int J Mar Navig Saf Sea Transp. 2016; 10(1): 19-26.

47. Oldenburg M, Harth V, Manuwald U, et al. Hospitalization due to cancer among German seafarers. Am J Ind Med. 2015; 58(4): 456-463, doi: 10.1002/ajim.22423, indexed in Pubmed: 25712579.

48. Fulmer S, Buchholz B. Ergonomic exposure case studies in Massachusetts fishing vessels. Am J Ind Med. 2002; Suppl 2: 10-18, doi: 10.1002/ajim.10086, indexed in Pubmed: 12210677.

49. WHO. Controlling the global obesity epidemic. http://www.who. int/nutrition/topics/obesity/en/ (Accessed December 19, 2015).

50. Jensen O, Flores A, Bygvraa DA, et al. A Review of Epidemiological Studies in Latin American Fishing. J Agromedicine. 2019; 24(4): 341-350, doi: 10.1080/1059924X.2019.1639575, indexed in Pubmed: 31293219. 